DE DE GRUYTER OPEN
Przedsiębiorczość i Zarządzanie Entrepreneurship and Management University od Social Sciences Publishing House

ISSN 1733-2486

Volume XVI, Issue 1, pp. 197-210

DOI 10.1515/eam-2015-0013

Tomasz Uryszek

University of Lodz

\title{
Long-Term Borrowing and Intergenerational Redistribution of Public Debt. The Case of Central and Eastern EU Member States
}

\begin{abstract}
The paper analyses the burden on the future generation resulting from the need to repay public debt in Central and Eastern EU Member States. The main theme is accompanied by the following research hypothesis: imbalance in public finances makes public authorities use long-term government securities more intensely. The hypothesis was verified based on the analysis of statistical data from Eurostat, European Central Bank and the OECD.
\end{abstract}

Key words: public debt, term structure, long-term government securities.

\section{Introduction}

Imbalance in public finances across the globe increases the demand for financial resources coming from loans, borrowings or the issuing of debt instruments. Minimising the liquidity risk for state budgets and debt refinancing risk, public debt managers strive to replace short-term debt with long-term instruments. Instruments with maturities up to several or even several dozen years are used more and more frequently. It means shifting the financing of current consumption expenditure onto the next generations, which may restrict growth possibilities in the future. The problem faces not only highly developed countries but also developing and the fastest growing economies. On the one hand, they are forced to struggle with excessive deficit and public 
debt while, on the other hand, they use public debt to finance current and investment expenditure. Relatively good ratings of public debt securities and increasing investors' trust let these countries take out long-term liabilities.

The paper aims at analysing the burden on the future generation caused by the need to repay public debt in Central and Eastern EU Member States. The principal objective is accompanied by the following research hypothesis: imbalance in public finances increases the use of public debt securities with long maturity periods. The thesis was verified based on statistical data from Eurostat, European Central Bank and the OECD databases. The study was conducted for 11 EU Member States: Bulgaria, Czech Republic, Estonia, Croatia, Latvia, Lithuania, Hungary, Poland, Romania, Slovakia, and Slovenia. The research covered the period 2002-2013.

\section{The concept of intergenerational public debt redistribution}

Intergenerational redistribution effects in the field of public finances refer, inter alia, to tax aspects, transfers and public debt [Lindbeck, Weibull 1986, pp. 239-267]. They are discussed in the context of their long-term impact upon the economy [Barro 1974, pp. 1095-1117]. To describe the mechanism we use, e.g., the theory of permanent income and rigid, sustainable budget constraints for public authorities [Barro 1989, pp. 37-54]. The assumptions of intergenerational redistribution model are challenged [Carmichael 1982]. However, in literature we can find a view that the authorities may, to a certain extent, be forced to shift the burden to future generations [Miles and Cerny 2006; Laffargue 2009, pp. 79-104] even though it could provoke negative effects dangerous for the economy [Heller 2003, pp. 2-3]. The government, wishing to finance specific expenditure categories, faces a dilemma whether it should increase taxes or take on public debt. By choosing the second option, it may, additionally, delay the necessity of payments for the current consumption and shift the repayment of some of its liabilities to the next generation.

Shifting the financing of current expenditure (current consumption) to the next generation means its representatives will have to pay all associated costs. Under such circumstances, not only the needs of the next generation are ignored but also its standard of living is threatened by such costs [see: Tabellini 1991]. Besides, one should worry about the possibility that the next generation will do the same and will postpone some of its current expenditure by the following several dozen years. It is possible due to financial markets development and relatively high ratings given also to countries with excessive debt volumes [see: Gaillard 2014, pp. 208-224; Téllez-Valle and Martín-García 2014, pp. 16-33]. This, in turn, may result in intergenerational public debt rollover 
at a large scale. Such a permanent imbalance of public finances may reduce the credibility of public authorities as creditors, lower the ratings of their debt securities and provoke further, increasing problems of the sector in individual countries.

Wishing to avoid such problems, the governments may try and limit public expenditure. Recently growing problems with excessive budget deficits and public debt have made many countries follow this line. That solution, however, is very difficult [for more see, e.g.: Głuchowski et al. 2005; Piotrowska-Marczak 2008, pp. 686-690]. The value and structure of public expenditure are direct consequences of tasks assumed by the State and are determined by the adopted model of the economic system. Problems with the scale and structure of expenditure result from both economic and financial as well as legal conditions, which are deeply rooted in historical and present situation [for more see: Kosikowski 2011, pp. 111-123]. Some spendings are „rigid” [Owsiak 2005, pp. 575-577], meaning they must be paid irrespective of the economic standing of the country, since they have been provided for in laws and executive acts. Secondly, expenditure cuts in the social area are negatively perceived by the public opinion. Hence reductions are usually limited to „flexible” expenditure (e.g. investment outlays), which may improve economic potential and boost the growth of individual countries.

On the other hand, governments in many countries (even those heavily indebted) try to stimulate the economy with additional public expenditure designed to increase demand or support economic operators (often rescuing them from bankruptcy). Hence a question emerges: should we restrict such expenditure or, on the contrary, should we use it as a tool in support of economic growth. Independently of the adopted solution, most of the Central and Eastern EU Member States run rather high budget deficits, which must be financed. The only decision to take is the time horizon for the maturity of debt instruments issued to cover the deficits. Very long maturity shall mean shifting some of the debt on the next generation.

\section{Methodology and data}

The idea of intergenerational redistribution of public debt links to the debt refinancing risk management and budget liquidity risk. Debt managers limit the risk by using financial instruments with longer maturities. Thus, to evaluate the scope of redistribution we may use the measures of refinancing risk. They have been discussed in literature for many years already [see e.g.: Luckett 1964, pp. 148-157]. Not all of them can be applied in comparative studies including many countries. Obstacles include the absence of data or various 
calculation methods in individual statistical systems (which makes the results incomparable), but also limited credibility of data used for calculations [Seung 2009, pp. 510-532]. Hence for empirical analyses we use the average time to maturity - ATM ratio. It is a synthetic measure of refinancing risk used in international comparisons and calculated in a standardised way by, e.g., the European Central Bank and the OECD. The ATM indicator can be interpreted as an average time for which a debt is repaid. High value of the indicator, representing long repayment periods, suggests lower refinancing risk (the need to raise resources to repay the debt occurs relatively rarely) [Uryszek 2011, pp. 66-77]. The ATM method is well recognized in the literature and used for many years (the way of its calculation is sometimes slightly different, but the idea always stays the same) to assess the government debt instruments market [Schmuklera and Vesperoni 2006, pp. 183-207] as well as to calculate the level of investment risk of bonds portfolios [Rivel 1949, pp. 342-347]. We must remember that ATM, as the average measure, can give misleading results [see: Yawitz et al. 1975, pp. p325-333]. However, ATM can be used for initial analyses. Is has also been used in the literature for international comparisons [see e.g.: Colliac and Lapteacru 2008, pp. 94-111; Schmuklera and Vesperoni 2006, pp. 183-207].

In order to assess intergenerational redistribution of public debt more profoundly we must analyse long-term liabilities of the EU Member States. The paper studies the primary term structure of public liabilities and focuses on debt instruments with the maturity between $15-30$ and more than 30 years. Primary maturity structure of such instruments enables to assess the average period for which public debt has been taken on, from the moment it was issued until it has been repaid. It informs about debt maturity periods and helps, inter alia, assess the use of long-term debt instruments by public authorities in different countries.

In the context of the objective of this paper we should pay special attention and check whether the lowering of refinancing risk by extending debt maturity does not shift repayment periods to future generations. To ensure the comparability of the results for particular countries, the statistical data were taken from Eurostat, European Central Bank and the OECD (instead of the national statistical offices). The study was conducted for 11 Central and Eastern EU Member States, already mentioned in the Introduction. These have been countries in transition from centrally planned to free market economy, currently being at the different level of development, but, generally speaking, having similar history and experience. The research covered the period 20022013. 


\section{Public debt in Central and Eastern EU Member States}

Public debt in Central and Eastern EU Member States is relatively lower than that of the so called "Fifteen". This is due to several factors. Firstly, the history of free market economy in these countries is much shorter than in the countries of the „old EU”. They began taking debt as late as in the 1990s. We should also stress that in some of the countries included in the survey indebtedness has not increased rapidly (see Table 1). Moreover, some of them managed even to significantly reduce public debt. The latter, in turn, results from the need to take care of the stability of public finances and of the economy. Negative changes in this respect could reduce the ratings by rating agencies and cause further negative effects for the economy. Rating agencies very carefully analyse macroeconomic variables of the Central and East European countries, which they consider emerging markets. Evaluation procedures in this case are very detailed [Erdem \& Varli 2014, pp. 42-57]. 


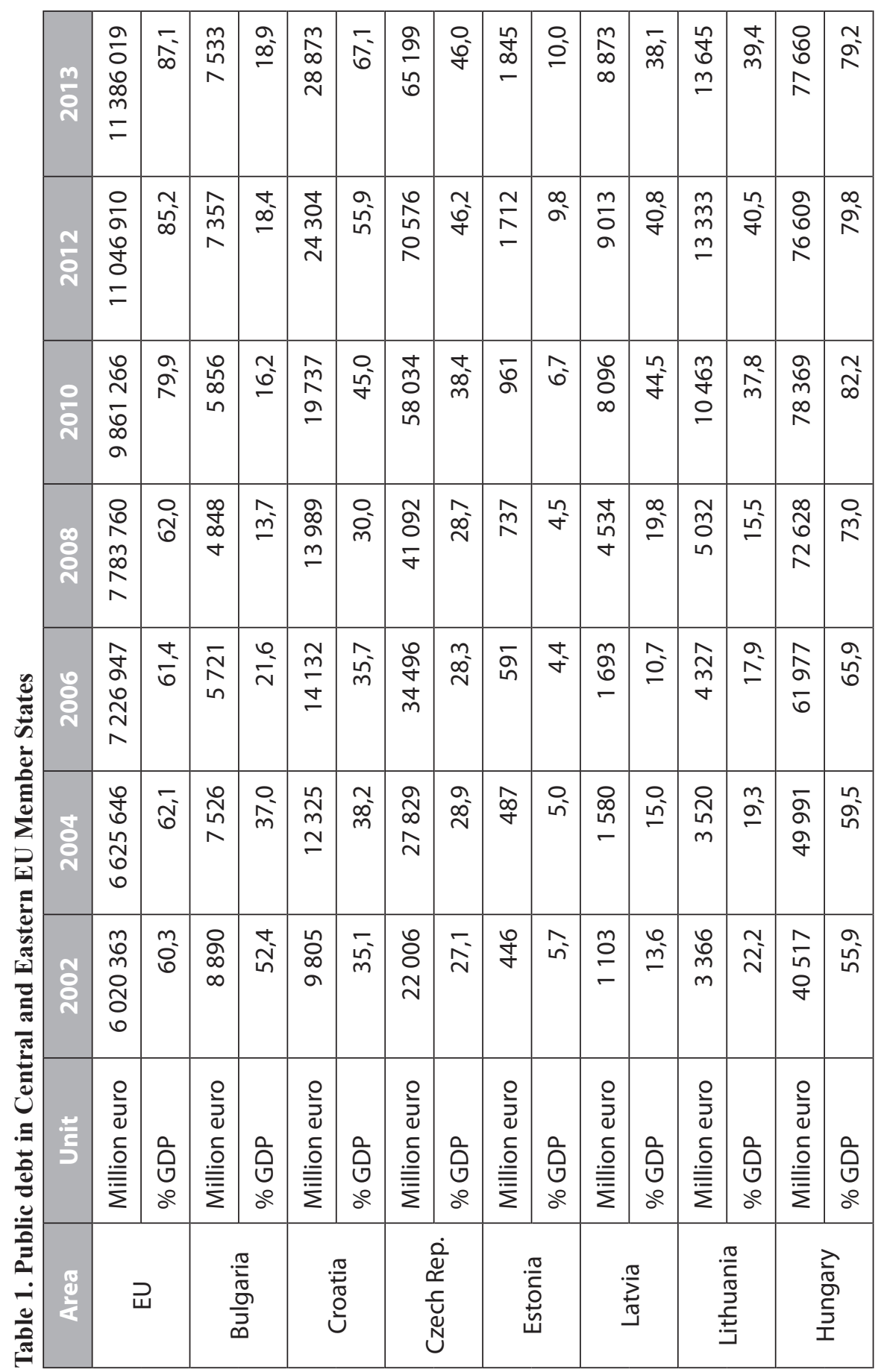




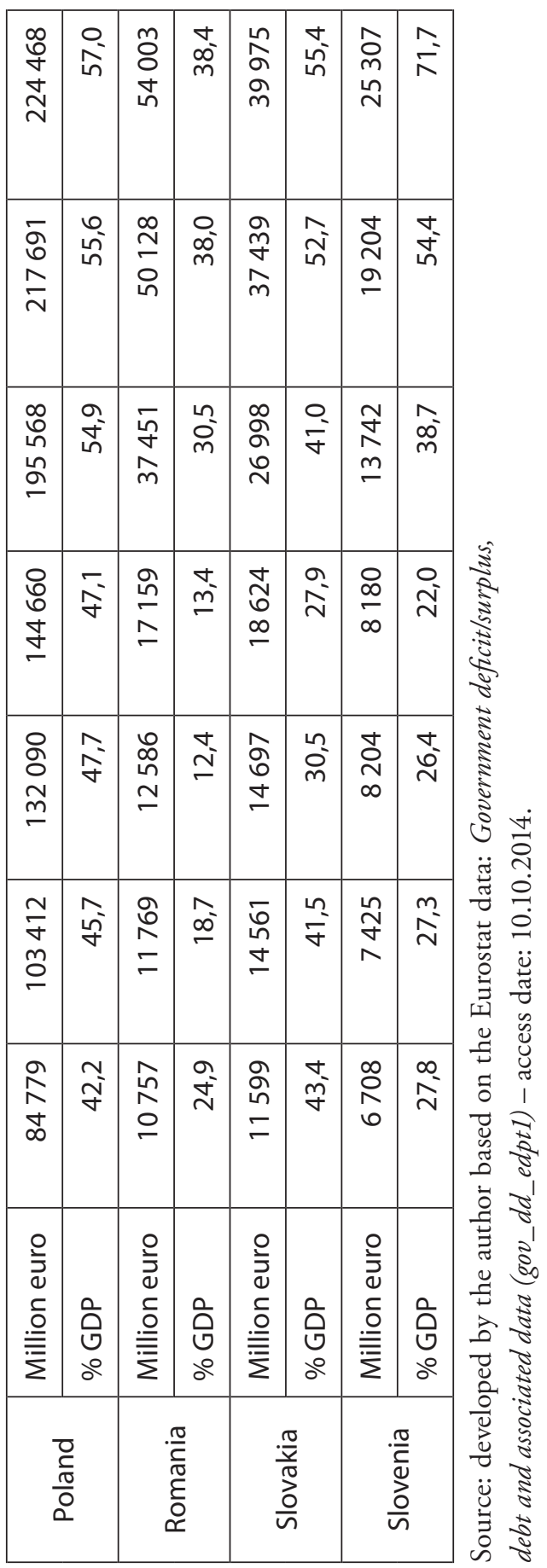


As one could expect, recent financial crisis considerably increased the debt in most analysed countries. It is worth noting, however, that even then all the Central and Eastern EU Member States (except of Hungary in 2006-2013 and Croatia in 2013) formally met the fiscal criterion of the Maastricht Treaty connected with the maximum public debt volume. Hungary introduced bold reforms aimed at reducing public debt. Nevertheless, most of the surveyed countries ran relatively high budget deficits which made them issue public debt securities. Public debt management called for an active shaping of the debt structure in terms of its origins, instruments, currencies and periods. Management of maturity periods had an impact upon the decisions on the maturity of applied debt instruments.

\section{Average time to maturity of public debt instruments}

The analysis of data concerning the average maturity of the debt issued by the public sector does not suggest any problems with shifting the liabilities to future generations. An average ATM in analysed countries was ca. 5.5 years. In most countries little extension was recorded and the changes were minor. Only in Bulgaria ATM clearly decreases. Details are presented in Table 2.

Table 2. Average time to maturity of public debt in Central and Eastern EU Member States (by years)

\begin{tabular}{|c|c|c|c|c|c|c|c|}
\hline Country & 2002 & 2004 & 2006 & 2008 & 2010 & 2012 & 2013 \\
\hline Bulgaria & 10,1 & 7,9 & 7,5 & 7,2 & 7,1 & 6,1 & 6,7 \\
\hline Croatia & $\mathrm{n} / \mathrm{a}$ & $\mathrm{n} / \mathrm{a}$ & $\mathrm{n} / \mathrm{a}$ & $\mathrm{n} / \mathrm{a}$ & $\mathrm{n} / \mathrm{a}$ & $\mathrm{n} / \mathrm{a}$ & $\mathrm{n} / \mathrm{a}$ \\
\hline Czech Rep. & 3,2 & 5,1 & 6,2 & 6,4 & 6,3 & $\mathrm{n} / \mathrm{a}$ & $\mathrm{n} / \mathrm{a}$ \\
\hline Estonia & 6,0 & 5,0 & 5,0 & 7,0 & 6,0 & 5,0 & 5,0 \\
\hline Hungary & $\mathrm{n} / \mathrm{a}$ & $\mathrm{n} / \mathrm{a}$ & $\mathrm{n} / \mathrm{a}$ & $\mathrm{n} / \mathrm{a}$ & 6,6 & 5,9 & 5,0 \\
\hline Latvia & 4,8 & 5,5 & 6,4 & 5,0 & 6,7 & 6,2 & 5,7 \\
\hline Lithuania & 3,5 & 4,1 & 4,6 & 4,5 & 4,6 & 4,7 & 4,6 \\
\hline Poland & 4,0 & 4,0 & 5,0 & 5,0 & 5,0 & 5,0 & 5,0 \\
\hline Romania & 4,1 & 4,8 & 7,6 & 4,0 & 5,7 & 4,1 & 4,4 \\
\hline Slovakia & 3,3 & 4,7 & 5,1 & 4,7 & 5,7 & $\mathrm{n} / \mathrm{a}$ & $\mathrm{n} / \mathrm{a}$ \\
\hline Slovenia & 6,5 & 5,6 & 5,7 & 6,0 & 6,1 & 6,1 & 5,4 \\
\hline
\end{tabular}

Source: developed by the author based on the European Central Bank data: Statistical Data Warehouse and OECD data: OECD.StatExtracts - access date: 10.10.2014. 
The analysis of ATM ratios does not allow to conclude whether the risk of shifting the repayment of public debt to the next generation is high in analysed countries. Average maturity time of public debt is a few years and thus future generations will hardly be effected.

We cannot also clearly link the increase in public debt volume with the extension of average maturity of debt instruments in all countries covered by the study. Correlation analysis for these two variables showed strong positive statistical relationship in five cases (out of 9, for which data on public debt and ATM were available). In other countries it was minor (or even negative). It may mean that increasing demand of public authorities for financial resources in some analysed countries was largely covered by short- and medium-term debt instruments.

However, we must bear in mind that average maturity ratios inform us only about average periods for which public debt is taken and their interpretation may be mistaken. Hence, in order to deepen the analysis it is necessary to analyse long-term debt in EU countries.

\section{Long-term instruments in the structure of public debt}

The share of debt instruments with very long maturities in the total public debt structure was ca. $14 \%$ in the period covered by the study (see Table 3 ). The share of instruments with maturities 15-30 years was much bigger than that of debt instruments with maturities exceeding 30 years. The share of the first group in public debt structure in the years 2012 and 2013 ranged from $5.3 \%$ in the Czech Republic (in 2012) to 40\% in Latvia in 2013. Instruments with maturities exceeding 30 years accounted for $0.1 \%$ of the debt in Croatia and over 5\% in Slovakia. These values may seem insignificant but we must remember that they represent millions or billions of euro which will be paid back for over 15 or even 30 years. That is clearly visible when we analyse per capita amounts. 


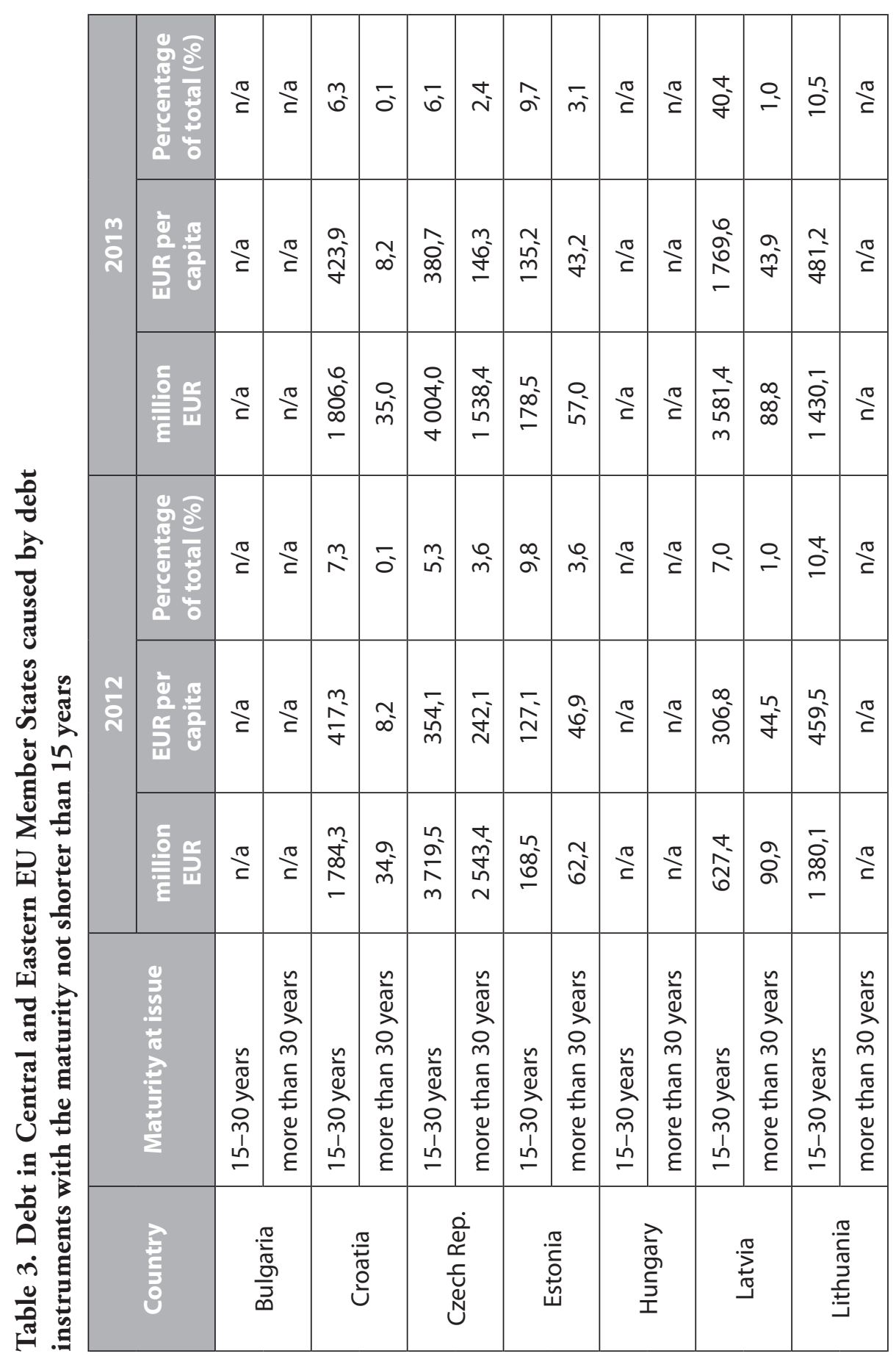




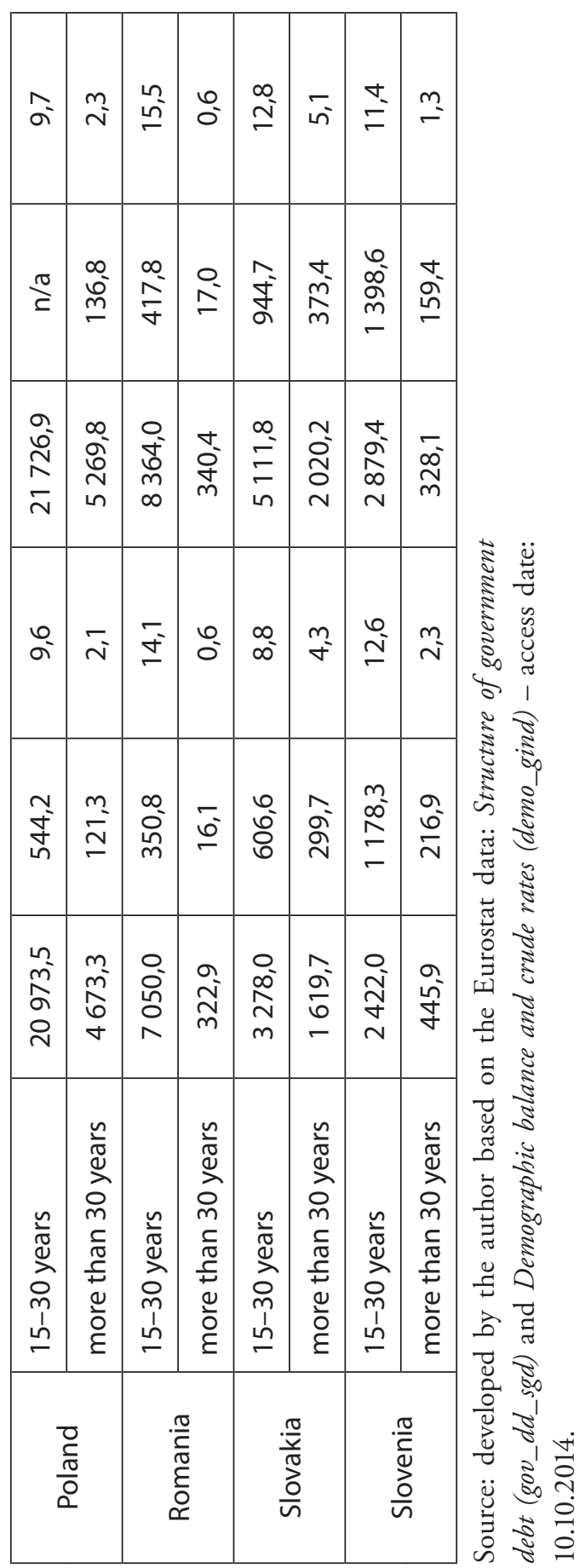


Analyses of long-term debt should be confronted with the prior assessment of average maturities. We may conclude that relatively low ATM ratios do not mean debt instruments with very long maturities have been given up. Although their share in the total public debt is relatively small for most of the analysed countries, it cannot be considered negligible.

\section{Conclusion}

Conducted analyses let us conclude that currently intergenerational debt redistribution is not the major issue of public finances in Central and Eastern EU Member States. Increasing public debt in these countries does not imply proportional increases of debt with very long maturities. That is demonstrated by average maturity ratios for public debt instruments, which amount to several years in the countries included in the study. It does not mean, however, that the problem does not exist. The countries use debt instruments with maturities of at least 15 years (and also exceeding 30 years). It means some public liabilities will have to be paid for many years to come and may also be shifted to the next generation. Thus assumptions of the initial hypothesis can be confirmed. Significant use of long-term debt instruments means the Central and Eastern EU Member States purposefully shift some of their financial commitments to the next generation. If the practice intensifies, it may significantly impact imbalances in the public finances in a relatively distant future (for the next generation). In order to avoid it, these countries should not only closely scrutinise debt refinancing risk in short- and medium-term but also take care of long-term debt structure by limiting the use of instruments with maturities reaching several dozen years.

\section{Bibliography}

Barro R.J. (1974), Are Government Bonds Net Wealth?, "Journal of Political Economy”, Vol. 82, Issue 6.

Barro R.J. (1989), The Ricardian Approach to Budget Deficits, "Journal of Economic Perspectives", Vol. 3, Issue 2.

Carmichael J. (1982), On Barro's Theorem of Debt Neutrality: The Irrelevance of Net Wealth, "American Economic Review", Vol. 72, Issue 1.

Colliac S., Lapteacru I. (2008), Three countries' debt profiles: Average maturities in Mexico, Brazil, and Russia, "Journal of Multinational Financial Management", Vol. 18 Issue 2.

Erdem O., Varli Y. (2014), Understanding the sovereign credit ratings of emerging markets, "Emerging Markets Review", Vol. 20. 
Gaillard N. (2014), What Is the Value of Sovereign Ratings?, "German Economic Review", Vol. 15, Issue 1.

Głuchowski J., Pomorska A., Szołno-Koguc J. (ed.) (2005), Ekonomiczne i prawne problemy racjonalizacji wydatków publicznych, Wydawnictwo Uniwersytetu Marii Curie-Skłodowskiej, Lublin.

Heller P.S. (2003), Who Will Pay? Coping with Aging Societies, Climate Change, and Other Long-Term Fiscal Challenges, International Monetary Fund.

Kosikowski C. (2011), Naprawa finansów publicznych w Polsce, Wydawnictwo Temida 2, Białystok.

Laffargue J.-P. (2009), Intergenerational Transfers and the Stability of Public Debt with Short-Lived Governments, "Mathematical Population Studies", Vol. 16, Issue 1.

Lindbeck A., Weibull J.W. (1986), Intergenerational Aspects of Public Transfers, Borrowing and Debt, Scandinavian Journal of Economics, Vol. 88, Issue 1.

Luckett D.G. (1964), On Maturity Measures of the Public Debt, "Quarterly Journal of Economics", Vol. 78, Issue 1.

Miles D., Cerny A. (2006), Risk, return and portfolio allocation under alternative pension systems with incomplete and imperfect financial markets, "Economic Journal", Vol. 116, Issue 511.

Owsiak S. (2005), Finanse publiczne. Teoria i praktyka, PWN, Warszawa.

Piotrowska-Marczak K. (2008), Zjawisko statego wzrostu wydatków publicznych [in:] C. Kosikowski, E. Ruśkowski (ed.), Finanse publiczne i prawo finansowe, Wolters Kluwer, Warszawa.

Rivel R.B. (1949), The Use of Average Maturity in the Analysis of Commercial Bank Investments, "Journal of Finance", Vol. 4, Issue 4.

Seung J.L. (2009), How Information Quality of Macro Aggregates Affects Sovereign Risk: An Empirical Investigation, "Review of International Economics", Vol. 17, Issue 3.

Schmuklera S.L., Vesperoni E. (2006), Financial globalization and debt maturity in emerging economies, "Journal of Development Economics", Vol. 79, Issue 1.

Tabellini G., (1991), The politics of intergenerational redistribution, "Journal of Political Economy", Vol. 99, Issue 2.

Téllez-Valle C., Martín-García M. (2014), Evolution of Sovereign Rating Models in the Current Crisis, "GCG: Revista de Globalización, Competitividad \& Gobernabilidad", Vol. 8, Issue 1.

Uryszek T. (2011), Term Structure of Public Debt and Refinancing Risk in the Economic and Monetary Union, "Folia Oeconomica Stetinensia", no. 10 (18). 
Yawitz J.B., Hempel G.H., Marshall W.J. (1975), The Use of Average Maturity as a Risk Proxy in Investment Portfolios, "Journal of Finance", Vol. 30, Issue 2. 